\title{
Inheritance of allelic variants of the kappa-casein gene by cows
}

\author{
Radik Shaidullin ${ }^{1 *}$, Gazimzyan Sharafutdinov ${ }^{1}$, Anastasia Moskvicheva ${ }^{1}$, Tagir Faizov ${ }^{2}$, and Yusupzhan Yuldashbaev ${ }^{3}$ \\ ${ }^{1}$ Kazan State Agrarian University, Kazan 420015, Russia \\ ${ }^{2}$ Federal Center for Toxicological, Radiation and Biological Safety, Kazan 420075, Russia \\ ${ }^{3}$ Russian State Agrarian University - Moscow Agricultural Academy named after K.A. Timiryazev, Moscow 127550, Russia
}

\begin{abstract}
The inheritance of allelic variants of the kappa-casein gene from bulls with different genotypes and their influence on the milk production of daughters were studied. For research, PCR diagnostics of daughters in the herds of black-and-white cattle at the farms "Azeleevo" and "Vakhitovo" (OJSC "Red East Agro") was carried out, the fathers were two bulls LADDIE 135797213 with a genotypes CSN3 AB and LOMAX 10785322 with a genotype CSN3 BB. Based on the results of genotyping, the frequency of occurrence of genotypes $\mathrm{AA}, \mathrm{AB}, \mathrm{BB}$ kappa-casein and allelic variants $\mathrm{A}$ and $\mathrm{B}$ in daughters was calculated. The bull with the CSN3 AB genotype produced the largest number of offspring with the CSN3 AA genotype - 50.0-51.8\%, and the bull with the homozygous BB genotype produced $24-25 \%$ of daughters carrying the $\mathrm{BB}$ variant and $75-76 \%$ of the $\mathrm{AB}$ genotype. The frequency of occurrence of the Kappa-casein allele in the daughters of bulls with the genotype CSN3 BB was 0.63, which is almost 2 times more than the allele A. When comparing heifers with the same genotype (CSN3 AB), it was found that at the Azeleevo farm, the daughters of the bulls having the genotype BB of kappa-casein are superior to cows born from bulls with the genotype $\mathrm{AB}$ by the milk yield $(+36 \mathrm{~kg})$, mass fraction of fat and protein $(+0.01 \%)$, the amount of milk fat $(+2 \mathrm{~kg})$ and protein $(+2 \mathrm{~kg})$. In the group of first-calf heifers with the BB genotype, daughters of the producer with the BB genotype are superior by the milk yield $(+175 \mathrm{~kg})$, the mass fraction of fat in milk $(+0.1 \%)$, the amount of milk fat $(+12 \mathrm{~kg})$, the mass fraction of protein in milk $(+0.09 \%)$, the amount of milk protein $(+11 \mathrm{~kg})$. At the Vakhitovo farm, similar results in the group of $\mathrm{CSN} 3 \mathrm{AB}$ heifers born from the bulls with the BB genotype was observed
\end{abstract}

\section{Introduction}

Along with traditional breeding, new molecular genetic methods and techniques are used to increase the efficiency of breeding. A progressive and affordable method is the use of DNA markers [1-2].

One of the potential DNA markers of signs of dairy cattle productivity is the kappa-casein gene (CSN3) [3-6]. It is associated with milk protein and technological properties of cow milk [7-11]. The Kappacasein gene B allele is associated with a higher protein content in milk and better cheese-making properties of milk [12-15].

In traditional breeding, when selecting animals, attention is paid to phenotypic traits, while their genetic characteristics are not taken into account, which often does not fully realize the valuable genetic potential of parents. Moreover, genetic markers of economically useful traits are inherited codominantly and are a constant characteristic of the body [16-18].

Cow inheritance of allelic variants of the kappacasein gene from bulls with different genotypes has been little studied. This requires genotyping of the bulls, cows and their offspring of the first generation.

The aim is to establish the inheritance of allelic variants of the kappa-casein gene and the influence of genotypes of bull fathers on indicators of milk production of daughters.

\section{Materials and methods}

In order to study the effect of kappa-casein genotypes of father bulls on the daughters' milk productivity indicators, the breeding value was determined of 19 servicing bulls used in OAO "Krasny Vostok Agro", which are genotyped at the kappa-casein locus.

To study the inheritance of the alleles of the kappacasein gene, PCR diagnostics of daughters in the herds of black-motley cattle at "Azeleevo" (124 goals) and "Vakhitovo" (108 goals) farms (OJSC "Red East Agro") and the genotyping analysis data of bull fathers were carried out.

The daughters were genotyped by the kappa-casein gene using the DNA diagnostics; milk productivity was determined and analyzed during 305 days since the first lactation.

The frequency of occurrence of genotypes was determined by formula

$$
P=\frac{n}{N},
$$

where $\mathrm{P}$ is the frequency of a particular genotype;

\footnotetext{
* Corresponding author: tppi-kgau@bk.ru
} 
$n$ is the number of individuals with a certain genotype; $N$ is the total number of individuals.

The frequency of individual alleles was determined by formulas [19]:

$$
\begin{aligned}
P_{A} & =\frac{(2 n A A+n A B)}{2 N}, \\
Q_{B} & =\frac{(2 n B B+n A B)}{2 N},
\end{aligned}
$$

where $P_{A}$ is the frequency of allele A,

$Q_{B}$ is the frequency of allele $\mathrm{B}$,

$2 N$ is the total number of alleles.

Bulls of the Holstein breed were used: LADDIE 135797213 with the genotype CSN3 AB and LOMAX 10785322 with the genotype CSN3 BB.

The material for the molecular DNA testing was venous blood of animals. DNA was extracted using the Magnosorb kit (Interlabservis, Moscow), according to the manufacturer's instructions. The CSN3 gene was studied by the polymerase chain reaction followed by restriction fragment length polymorphism (PCR-RFLP) analysis using the 5'-ATAGCCAAATATATCCCAATTCAGT-3 'direct primer and 5'-TTTATTAATAAGTCCATGAATCTTG-3' primer [20]. Amplification was carried out using a DT-96 amplifier (Russia). We used a PCR mixture of the following composition: a pair of primers for amplification of the region of the gene, a mixture of nucleoside triphosphates $(2.5 \mathrm{~mm})$, magnesium chloride (25 mm), 10-fold buffer for PCR, Taq polymerase. For amplification of fragments of the kappa-casein gene, pairs of oligonucleotide primers synthesized at Syntol CJSC (Moscow, Russia) were used. Amplicons were subjected to restriction using Hinf I restriction enzymes (SibEnzyme, Russia) according to the manufacturer's recommendations.

The materials were statistically processed followed by the calculation of the arithmetic mean (M) and arithmetic mean error (m) in the Microsoft Excel 2007 software application. The level of reliability of the results was determined by the Student's criterion.

\section{Results}

At the first stage of the research, the overall influence was studied of the kappa-casein genotypes of father bulls on the milk production indicators of the daughters at the farm as a whole.

When analyzing the milk productivity of the daughters of the bulls with different kappa-casein genotypes, it was found that the milk yield from the daughters of the bulls with the CSN3 AA genotype exceeded the milk yield from their peers by $176-193 \mathrm{~kg}$ of milk ( $\mathrm{P}<0.001)$, but they are inferior in mass fraction of fat by $0.02-0.11 \%(\mathrm{P}<0.001)$ and the mass fraction of protein in milk - by $0.05-0.08 \%$ (Table 1 ).

The amount of milk fat $(211 \mathrm{~kg})$ and protein $(171 \mathrm{~kg})$ is high in bull dams with the CSN3 AA genotype, and the difference is significant compared to the CSN3 AB group $(\mathrm{P}<0.05-0.001)$.
The best level of realization of the genetic potential of milk yield was found in the daughters of the bulls with the CSN3 AA genotype; it amounted to $40.1 \%$ (Table 2).

A high level of realization of the genetic potential in the mass fraction of fat in milk was noted among the servicing bulls with the CSN3 BB genotype $-109.4 \%$, and in the mass fraction of protein, the highest result of the potential realization was shown by the daughters of the bulls with CSN3 AB $-102.2 \%$.

Thus, the daughters of the bulls with the AA genotype had a higher milk yield and yield of milk fat and protein, but they were characterized by lower rates of butter-fat content and protein content.

At the second stage of studies, the heritability was studied of the kappa-casein gene alleles by the daughters of two bulls: LADDIE 135797213 with the CSN3 AB genotype and LOMAX 10785322 with the CSN3 BB genotype.

Studies have found that in herds of dairy cattle of the Azeleevo and Vakhitovo farms, daughters with the genotypes CSN3 AA (50.0-51.8 \%) and CSN3 AB (43.1-46.4\%) were produced from the bulls with the genotype CSN3 AB; Kappa-casein allele B is 3 times less common than A allele (Table 3 ).

From the homozygous producers (CSN3 BB), only the B-allelic variant of the kappa-casein gene is inherited with a predominance of the CSN3 AB genotype (75-76 $\%$ ). The frequency of occurrence of B allele B was 0.620.63 , which is almost 2 times more than allele $\mathrm{A}$.

Thus, not taking into account the influence of mothers, father bulls with allele B of the kappa-casein gene are more likely to receive daughters with the $\mathrm{AB}$ genotype for kappa-casein. This is due to the fact that the B-allele of kappa-casein is transmitted to calves according to Mendel's laws by the type of coding. Cleavage in F2 progeny by genotype 1:2:1 and daughters from such father bulls have an increased frequency of occurrence of allele B.

Therefore, when bulls with the CSN3 genotype are used, the probability of inheritance of the desired B kappa-casein allele in daughters increases by 2.5 times, compared with the use of bulls with the CSN3 AB genotype.

Our studies are consistent with the studies by Yu.A. Mikhailova [21], according to which the bulls with the CSN3 genotype of BB daughters inherit the Ballele of kappa-casein twice as high as that of the Aallelic variant. Daughters inherit the B-allelic variant in half with the A-allelic genotype from bulls with the CSN3 AB genotype, and the occurrence of the B-allele of kappa-casein in the offspring is inherited either equally or half as much as in the A-allelic variant.

Table 4 shows the effect of father bulls with different kappa-casein genotypes on the milk yield of their daughters in different herds.

It was established that the daughters of the same bulls have slightly different levels of milk yield. These differences may also be associated with the genetic influence of their mothers.

At the Azeleevo LCD, the bull LADDIE 135797213 has the most productive daughters with the CSN3 AB genotype with a milk yield of $5580 \mathrm{~kg}$, a mass fraction of 
fat of $4.09 \%$ and protein of $3.30 \%$. At Vakhitovo farm, the best productivity indicators were found in daughters with the same genotype $\mathrm{CSN} 3 \mathrm{AB}$, but with a greater difference.

In the LOMAX 10785322 bull, descendants with the CSN3 AB genotype with a milk yield of 5616-5802 kg, a mass fraction of milk fat of $4.10-4.12 \%$, and a milk fat yield of 230-239 kg have an advantage at both farms.

When comparing heifers with the same genotype, it was found that in the Azeleevo livestock complex, daughters of the bull with genotype BB of kappa-casein in the CSN3 AB group have an advantage over cows born from the bull with genotype $\mathrm{AB}$ in milk yield $(+36 \mathrm{~kg})$, mass fraction of fat and protein $(+0.01 \%)$, the amount of milk fat $(+2 \mathrm{~kg})$ and protein $(+2 \mathrm{~kg})$. In the group of firstcalf heifers with the BB genotype, daughters of the producer with the BB genotype are more productive in terms of milk yield by $175 \mathrm{~kg}$, the mass fraction of fat in milk - by $0.1 \%$, the amount of milk fat - by $12 \mathrm{~kg}$, the mass fraction of protein in milk - by $0.09 \%$, the amount of milk protein - by $11 \mathrm{~kg}$.

At the Vakhitovo farm, there is a similar picture of the advantage of bull daughters with the BB genotype, which amounted to $51 \mathrm{~kg}, 2 \mathrm{~kg}, 0.03 \%, 4 \mathrm{~kg}$, and $203 \mathrm{~kg}$, $0.03 \%$ to the BB group, respectively; $10 \mathrm{~kg}, 0.04 \%, 9 \mathrm{~kg}$, which is confirmed by the data as a whole for two farms.

The use of bulls with the CSN3 genotype BB does not affect the milk yield of their daughters; therefore, they can be successfully used for breeding. Therefore, it can be recommended to use bulls with the CSN3 AB and CSN3 BB genotypes in breeding in order to obtain highly productive daughters with the Kappa-casein allele $\mathrm{B}$ in the genome. Therefore, using the method of DNA diagnostics, it is necessary to identify bulls and cows with genotypes $\mathrm{AB}$ and $\mathrm{BB}$ of kappa-casein, conduct homogeneous selection of parental pairs and selection for breeding daughters with the allelic variant B of kappa-casein in the genotype.

Table 1. Milk productivity of daughters of servicing bulls, carriers of various kappa-casein genotypes.

\begin{tabular}{|c|c|c|c|c|c|c|}
\hline \multirow{2}{*}{$\begin{array}{c}\text { Bulls' CSN3 } \\
\text { genotype }\end{array}$} & \multirow{2}{*}{$\begin{array}{c}\text { A number of } \\
\text { bulls }\end{array}$} & \multicolumn{5}{|c|}{ Milk productivity of the daughters } \\
\hline & & $\begin{array}{c}\text { Milk yield, } \\
\text { kg }\end{array}$ & $\begin{array}{c}\text { Fat content, } \\
\%\end{array}$ & $\begin{array}{c}\text { Milk fat } \\
\text { content, } \mathrm{kg}\end{array}$ & $\begin{array}{c}\text { Protein } \\
\text { content, } \\
\%\end{array}$ & $\begin{array}{l}\text { Milk protein } \\
\text { content, } \mathrm{kg}\end{array}$ \\
\hline AA & 11 & $5326 \pm 22$ & $3.96 \pm 0.01$ & $211 \pm 1.3$ & $3.21 \pm 0.01$ & $171 \pm 1.0$ \\
\hline $\mathrm{AB}$ & 7 & $5133 \pm 26$ & $3.98 \pm 0.01$ & $204 \pm 1.4$ & $3.26 \pm 0.01$ & $167 \pm 1.2$ \\
\hline $\mathrm{BB}$ & 1 & $5150 \pm 53$ & $4.07 \pm 0.02$ & $210 \pm 2.2$ & $3.29 \pm 0.01$ & $169 \pm 2.0$ \\
\hline \multicolumn{2}{|c|}{$\mathrm{AA}$ to $\pm \mathrm{AB}$} & $193 * * *$ & -0.02 & $7 * * *$ & $-0.05 * * *$ & $4 *$ \\
\hline \multicolumn{2}{|c|}{ AA to $\pm \mathrm{BB}$} & $176^{* *}$ & $-0.11 * * *$ & 1 & $-0.08 * * *$ & 2 \\
\hline \multicolumn{2}{|c|}{$\mathrm{AB}$ to $\pm \mathrm{BB}$} & -17 & $-0.09 * * *$ & $-6^{*}$ & $-0.03 *$ & -3 \\
\hline
\end{tabular}

Table 2. The level of realization of the genetic potential of the signs of milk production in the daughters of the servicing bulls, depending on the genotype of kappa-casein

\begin{tabular}{|c|c|c|c|c|c|c|c|}
\hline CSN3 genotype & $\begin{array}{c}\text { A number } \\
\text { of bulls }\end{array}$ & \multicolumn{3}{|c|}{ Genealogical index of the bulls } & \multicolumn{2}{c|}{$\begin{array}{c}\text { Level of realization of the genetic } \\
\text { potential, \% }\end{array}$} \\
\cline { 3 - 8 } & & $\begin{array}{c}\text { By milk yield, } \\
\mathrm{kg}\end{array}$ & By fat, \% & $\begin{array}{c}\text { By protein, } \\
\%\end{array}$ & $\begin{array}{c}\text { By milk } \\
\text { yield }\end{array}$ & By fat & By protein \\
\hline AA & 11 & 13295 & 3.73 & 3.20 & 40.1 & 106.1 & 100.3 \\
\hline AB & 7 & 13005 & 3.98 & 3.19 & 39.5 & 100.0 & 102.2 \\
\hline BB & 1 & 13028 & 3.72 & 3.32 & 39.5 & 109.4 & 99.1 \\
\hline
\end{tabular}

Table 3. Frequency of alleles and genotypes of kappa-casein in daughters of bull fathers

\begin{tabular}{|c|c|c|c|c|c|c|c|c|c|c|}
\hline \multirow{3}{*}{$\begin{array}{c}\text { Genotype } \\
\text { of bulls by } \\
\text { CSN3 }\end{array}$} & \multirow{3}{*}{$\begin{array}{l}\text { Nickname and inventory } \\
\text { number of bulls }\end{array}$} & \multirow[t]{3}{*}{$\mathrm{n}$} & \multicolumn{6}{|c|}{ CSN3 genotype frequency } & \multicolumn{2}{|c|}{ Allele frequency } \\
\hline & & & \multicolumn{2}{|c|}{ AA } & \multicolumn{2}{|c|}{$\mathrm{AB}$} & \multicolumn{2}{|c|}{$\mathrm{BB}$} & \multirow{2}{*}{$\mathrm{A}$} & \multirow[t]{2}{*}{$\mathrm{B}$} \\
\hline & & & $\mathrm{n}$ & $\%$ & $\mathrm{n}$ & $\%$ & $\mathrm{n}$ & $\%$ & & \\
\hline \multicolumn{11}{|c|}{ LC Azeleevo } \\
\hline $\mathrm{AB}$ & LADDIE 135797213 & 56 & 29 & 51.8 & 26 & 46.4 & 1 & 1.8 & 0.75 & 0.25 \\
\hline $\mathrm{BB}$ & LOMAX 10785322 & 68 & - & - & 51 & 75.0 & 17 & 25.0 & 0.37 & 0.63 \\
\hline \multicolumn{11}{|c|}{ LC Vakhitovo } \\
\hline $\mathrm{AB}$ & LADDIE 135797213 & 58 & 29 & 50.0 & 25 & 43.1 & 4 & 6.9 & 0.71 & 0.29 \\
\hline $\mathrm{BB}$ & LOMAX 10785322 & 50 & - & - & 38 & 76.0 & 12 & 24.0 & 0.38 & 0.62 \\
\hline \multicolumn{11}{|c|}{ Total } \\
\hline $\mathrm{AB}$ & LADDIE 135797213 & 114 & 58 & 50.9 & 51 & 44.7 & 5 & 4.4 & 0.73 & 0.27 \\
\hline BB & LOMAX 10785322 & 118 & - & - & 89 & 75.4 & 29 & 24.6 & 0.38 & 0.62 \\
\hline
\end{tabular}


Table 4. Milk productivity of daughters of the bulls with different kappa-casein genotypes in breeding herds

\begin{tabular}{|c|c|c|c|c|c|c|c|c|}
\hline \multirow{2}{*}{$\begin{array}{c}\text { Genotype } \\
\text { of bulls } \\
\text { by CSN3 }\end{array}$} & \multirow{2}{*}{$\begin{array}{l}\text { Nickname and } \\
\text { inventory } \\
\text { number of bulls }\end{array}$} & \multirow{2}{*}{$\begin{array}{l}\text { Genotype of } \\
\text { daughters } \\
\text { by CSN3 }\end{array}$} & \multirow[t]{2}{*}{$\mathrm{n}$} & \multicolumn{5}{|c|}{ Daughters' Productivity } \\
\hline & & & & $\begin{array}{l}\text { Milk yield, } \\
\text { kg }\end{array}$ & Fat, \% & Milk fat, $\mathrm{kg}$ & Protein, $\%$ & $\begin{array}{c}\text { Milk protein, } \\
\text { kg }\end{array}$ \\
\hline \multicolumn{9}{|c|}{ LC Azeleevo } \\
\hline \multirow[t]{3}{*}{$\mathrm{AB}$} & \multirow{3}{*}{$\begin{array}{c}\text { LADDIE } \\
135797213\end{array}$} & AA & 29 & $5560 \pm 78$ & $4.10 \pm 0.02$ & $228 \pm 3.8$ & $3.25 \pm 0.01$ & $180 \pm 2.6$ \\
\hline & & $\mathrm{AB}$ & 26 & $5580 \pm 83$ & $4.09 \pm 0.02$ & $228 \pm 3.7$ & $3.30 \pm 0.02$ & $184 \pm 2.8$ \\
\hline & & $\mathrm{BB}$ & 1 & 5245 & 3.98 & 209 & 3.30 & 173 \\
\hline \multirow[t]{2}{*}{$\mathrm{BB}$} & \multirow{2}{*}{$\begin{array}{c}\text { LOMAX } \\
10785322 \\
\end{array}$} & $\mathrm{AB}$ & 51 & $5616 \pm 63$ & $4.10 \pm 0,02$ & $230 \pm 3.1$ & $3.31 \pm 0.01$ & $186 \pm 2.1$ \\
\hline & & $\mathrm{BB}$ & 17 & $5420 \pm 79$ & $4.08 \pm 0.03$ & $221 \pm 3.7$ & $3.39 \pm 0.02$ & $184 \pm 2.9$ \\
\hline \multicolumn{9}{|c|}{ LC Vakhitovo } \\
\hline \multirow[t]{3}{*}{$\mathrm{AB}$} & \multirow{3}{*}{$\begin{array}{c}\text { LADDIE } \\
135797213\end{array}$} & AA & 29 & $5682 \pm 57$ & $4.11 \pm 0.02$ & $233 \pm 2.8$ & $3.27 \pm 0.01$ & $186 \pm 2.0$ \\
\hline & & $\mathrm{AB}$ & 25 & $5751 \pm 92$ & $4.13 \pm 0.02$ & $237 \pm 4.4$ & $3.31 \pm 0.01$ & $190 \pm 3.6$ \\
\hline & & $\mathrm{BB}$ & 4 & $5518 \pm 149$ & $4.08 \pm 0.06$ & $225 \pm 8.5$ & $3.37 \pm 0.01$ & $186 \pm 5.7$ \\
\hline \multirow[t]{2}{*}{$\mathrm{BB}$} & \multirow{2}{*}{$\begin{array}{l}\text { LOMAX } \\
10785322 \\
\end{array}$} & $\mathrm{AB}$ & 38 & $5802 \pm 64$ & $4.12 \pm 0.02$ & $239 \pm 2.9$ & $3.34 \pm 0.01$ & $194 \pm 2.1$ \\
\hline & & $\mathrm{BB}$ & 12 & $5721 \pm 97$ & $4.11 \pm 0.03$ & $235 \pm 4.9$ & $3.41 \pm 0.02$ & $195 \pm 2.8$ \\
\hline \multicolumn{9}{|c|}{ Total } \\
\hline \multirow[t]{3}{*}{$\mathrm{AB}$} & \multirow{3}{*}{$\begin{array}{c}\text { LADDIE } \\
135797213\end{array}$} & AA & 58 & $5621 \pm 48$ & $4.10 \pm 0.02$ & $230 \pm 2.4$ & $3.26 \pm 0.01$ & $183 \pm 1.6$ \\
\hline & & $\mathrm{AB}$ & 51 & $5664 \pm 62$ & $4.11 \pm 0.02$ & $233 \pm 2.9$ & $3.31 \pm 0.01$ & $187 \pm 2.3$ \\
\hline & & $\mathrm{BB}$ & 5 & $5495 \pm 117$ & $4.04 \pm 0.05$ & $222 \pm 6.2$ & $3.35 \pm 0.02$ & $184 \pm 4.7$ \\
\hline \multirow[t]{2}{*}{$\mathrm{BB}$} & \multirow{2}{*}{$\begin{array}{c}\text { LOMAX } \\
10785322\end{array}$} & $\mathrm{AB}$ & 89 & $5695 \pm 46$ & $4.11 \pm 0.01$ & $234 \pm 2.2$ & $3.32 \pm 0.01$ & $189 \pm 1.5$ \\
\hline & & BB & 29 & $5544 \pm 66$ & $4.09 \pm 0.02$ & $227 \pm 3.2$ & $3.39 \pm 0.01$ & $188 \pm 2.3$ \\
\hline
\end{tabular}

Similar results by high milk yields from cows of various breeds with the Kappa-casein B allele were found by Russian [22] and foreign scientists [23-25].

\section{Conclusion}

Based on the data obtained, we can conclude:

1. When using bulls with the CSN3 genotype BB, the probability of inheritance of the desired B kappa-casein allele is 2.5 times higher than when using bulls with the CSN3 AB genotype.

2. When using bulls with the genotype CSN3 AB and $\mathrm{CSN} 3 \mathrm{BB}$, it is possible to obtain highly productive daughters, especially those with a higher milk yield, having the kappa-casein allele B.

\section{References}

1. R. Tamarova, N. Yarlykov, Yu. Korchagina, Selection methods for increasing the milk yield of cows using genetic markers (Yaroslavl, 2014).

2. J. Ogorevc, T. Kunej, A. Razpet, P. Dovc, Animal Genetics 40, 832-851 (2009)

3. A. Gallyamova, S. Islamova, Dairy and beef cattle breeding 2, 17-18 (2008)

4. A. Ganiev, R. Shaidullinv, F. Sibagatullin, G. Sharafutdinov, A. Moskvicheva, S. Tyulkin, T. Faizov, Res. J. of Pharmaceutical, Biological and Chemical Sci. 9(6), 1504-1509 (2018)

5. B. Tanaskovska, S. Srbinovska, S. Andonov, S. Trojacanec, T. Nestoriovski, Z.T. Popovski, Int. J. of Agriculture Innov. and Res. 2, 266-270 (2016)

6. S. Tyulkin, R. Vafin, L. Zagidullin, T. Akhmetov, A. Petrov, F. Diel, Foods and Raw Materials 6(1), 154-162 (2018)
7. P. Di. Gregorio, A. Di. Grigoli, A. Di. Trana, M. Alabiso, G. Maniaci, A. Rando, C. Valluzzi, D. Finizio, A. Bonanno, Int. Dairy J. 17, 1-5 (2017)

8. A. Comin, M. Cassandro, S. Chessa, J. Dairy Sci. 91, 4022-4027 (2008)

9. C. Abeykoon, R. Rathnayake, M. Johansson, G.L.L.P. Silva, C. Ranadheera, A. Lundh, J. Vidanarachchi, Proc. Food Sci. 6, 348-351 (2016)

10. A. Perna, I. Intaglietta, E. Gambacorta, A. Simonetti, J. of Dairy Sci. 99, 3288-3294 (2016)

11. V. Bonfatti, G. Di Martino, A. Cecchinato, L. Degano, P. Carnier, J. Dairy Sci. 93, 3809-3817 (2010)

12. G. Goncharenko, G. Goryacheva, N. Rudishina, N. Medvedeva, E. Akulich, Bull. of Altai State Agrarian Univer. 12(110), 113-117 (2013)

13. F. Gustavsson, A. Buitenhuis, M. Johansson, H. Bertelsen, M. Glantz, N. Poulsen, M. Lindmark, H. Stalhammar, L. Larsen, C. Bendixen, M. Paulsson, A. Andren, J. of Dairy Sci. 97, 38663877 (2014)

14. V. Soloshenko, Z. Popovski, G. Goncharenko, V. Petukhov, N. Grishinf, N. Shishin, E. Kamaldinov, Res. J. of Pharmaceutical, Biological and Chemical Sci. 7(5), 982-989 (2016)

15. P. Di Gregorio, A. Di. Grigoli, A. Di. Trana, M. Alabiso, G. Maniaci, A. Rando, C. Valluzzi, D. Finizio, A. Bonanno, Int. Dairy J. 17, 1-5 (2017)

16. N. Zinovieva, O. Kostyunina, E. Gladyr, A. Bannikova, V. Kharzinova, P. Larionova, K. Shavyrina, L. Ernst, Zootechny 1, 8-10 (2010)

17. N. Strekozov, N. Zinovieva, P. Gorelov, V. Listratenkova, E. Konovalova, V. Chernushenko, L. Ernst, Agricultural Biology 2, 10-15 (2009)

18. A. Hamza, Z. Yang, X. Wang, R. Chen, H. Wu, A. Ibrahim, Agricultural J. 5, 283-285 (2010) 
19. E. Merkuryeva, Genetic Foundations of Breeding in Livestock (Moscow, 1977)

20. L. Kalashnikova, I. Dunin, V. Glazko et al., DNA technology for assessing farm animals (Forest Glades, VNIIplem, 1999)

21. Yu. Mikhailova, Bull. of the Agro-industrial complex of the Upper Volga 1(33), 93-97 (2016)

22. E. Kapelnitskaya, A. Shilova, Chief livestock specialist 4, 34-39 (2015)
23. A. Comin, M. Cassandro, S. Chessa, Dairy Sci. 91, 4022-4027 (2008)

24. A. Perna, I. Intaglietta, E. Gambacorta, A. Simonetti, J. of Dairy Sci. 99, 3288-3294 (2016)

25. A. Tsiaras, G. Bargouli, G. Banos, C. Boscos, American Dairy Sci. Association 88, 327-334 (2005) 